\title{
Study of cryogenic power generation application at LNG regasification terminal
}

\author{
AdhicahyoPrabowo ${ }^{1}$, and Sutrasno Kartohardjono, ${ }^{2, *}$ \\ ${ }^{1}$ Oil and Gas Procurement Section, Oil and Gas Division, PT PLN (Persero) Kantor Pusat, Jakarta 12160, Indonesia \\ ${ }^{2}$ Intensification Process Laboratory, Department of Chemical Engineering Universitas Indonesia, Kampus UI Depok 16424, \\ Indonesia.
}

\begin{abstract}
Cryogenic Power Generation or commonly called Cryopower is the generation of electricity by utilizing cold energy which one is produced at the LNG (liquefied natural gas) Regasification Terminal. Cold energy utilization has been applied in several countries, especially in Japan. In Indonesia, the regasification terminal has been built few, but in the future according to the Government of Indonesia's plan, some natural gas/LNG power plants will be built to meet the national electricity needs. It requires gas infrastructure, one of which is the regasification terminal. The aim of this study is to evaluate the effects of LNG flowrate on working fluid and cooling water flowrates as well as power needed and produced in the combine direct expansion and Rankine cycle processes. The flowrates and power calculations were conducted using UNISIM R390.1. Simulation results showed that the working fluid and cooling water flowrates increase with increasing LNG flowrate. The increased in the working fluid and cooling water flowrates also increased the power needed by the pumps and power produced by the turbines. Overall, the net power produced from the combine cycle increased with increasing the LNG flowrate.
\end{abstract}

\section{Introduction}

LNG (liquefied natural gas) is the liquid form of natural gas, which is stored at atmospheric pressure and temperature of around $-162^{\circ} \mathrm{C}$. For the application, $\mathrm{LNG}$ at the regasification terminal will be vaporized into natural gas at a given pressure before it can be supplied to the customer. Latent heat and sensible heat are required to superheat the natural gas vapor during the vaporization process [1]. The cold energy of LNG could be recovered and utilized as power generation, air separation, material freezing and intake air cooler, where the cryogenic power generation is the most effective one [2]. The LNG cold energy utilization can be implemented through direct expansion process, Rankine cycle process and combination of direct expansion and Rankine cycle processes [3].

The Government of Republic of Indonesia at present plans to add combined generating capacity throughout Indonesia with an additional total of 77.9 Giga Watt. The coal-fired power plant (PLTU) will be dominated by $41 \%$, the second is $31.3 \%$ gas-fired power plant, $18 \%$ hydropower (Hydroelectric Power Plant) and the remaining $9.7 \%$ is a Power Plant with renewable energy fuel. The composition shows that the gas requirement for Power Generation ranks second of all types of fuel. Based on the National Gas Policy 2015 - 2030 issued by the Ministry of Energy and Mineral Resources of the Republic of Indonesia, gas needed for the electricity sector averages around 2,067 MMSCFD by 2025 or about $26 \%$ of the total national gas requirement approximately 7,950 MMSCFD. Meanwhile, based on the National Gas Policy $2015-2030$ [4], gas production in 2025 is planned to be only 5,747 MMSCFD. This creates a gas supply deficit where there is a difference between gas supply and demand. This is due to the amount of domestic gas supply cannot keep up with gas demand. Due to inadequate availability of this domestic gas, in the future the Government needs to implement the import of LNG (Liquefied Natural Gas). In addition, starting in 2020 the portion of gas demand in the form of LNG becomes higher than gas pipelines where demand for LNG in 2020 reaches 1,147 MMSCFD and will increase twice in 2025 to 2,259 MMSCFD. It indicates that in the future the volume of LNG transactions in Indonesia will be even greater. This large volume of transactions will also require the construction of LNG infrastructure as a supporting element. The minimum LNG infrastructure that must be in place for LNG transactions to run is, among others, LNG Plant, LNG Shipping/Carrier and LNG Terminal/Terminal Regasification.

The LNG Regasification Terminal is one of the links in the LNG supply chain. At this regasification terminal, the LNG is converted back into the gas phase to be utilized by the end user [5].

* Corresponding author: sutrasno@che.ui.ac.id 


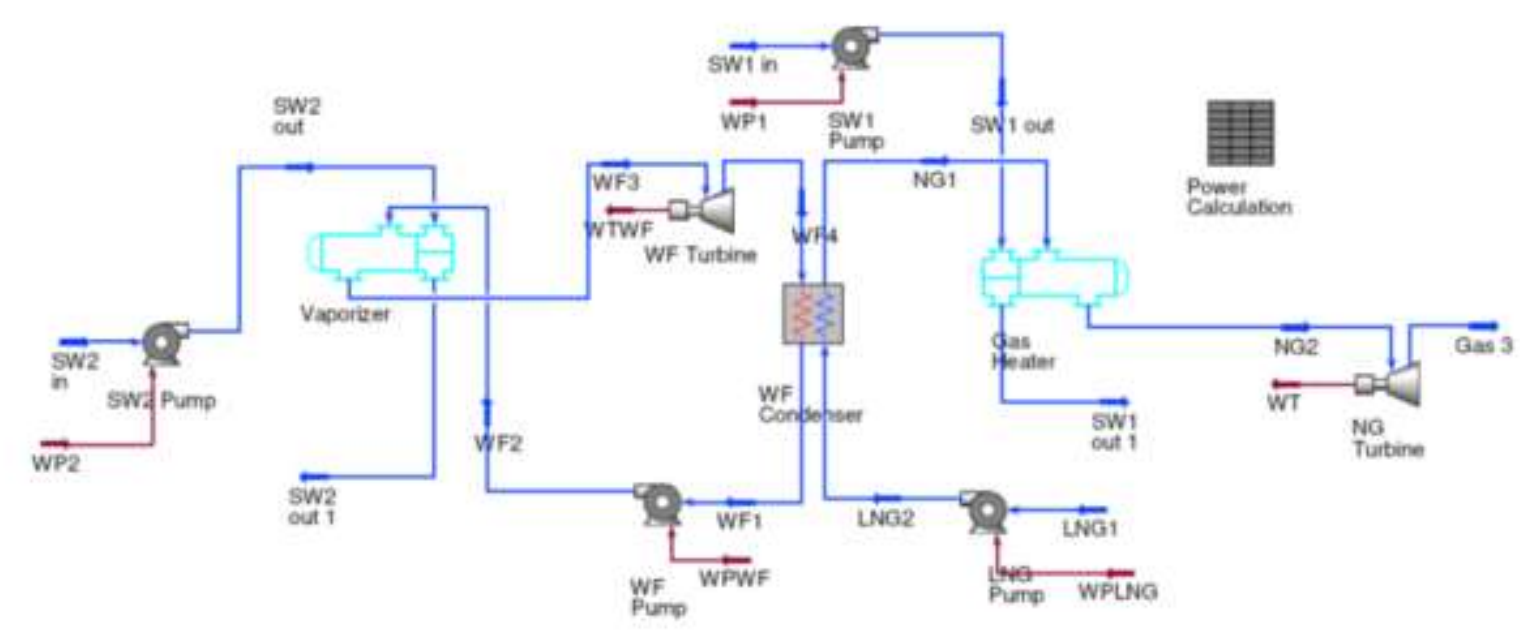

Fig. 1. Schematic diagram of Combine Direct Expansion and Rankine Cycle

The main process in the regasification of LNG is heat exchange where the LNG temperature in a liquid phase of $-162{ }^{\circ} \mathrm{C}$ is The LNG Regasification Terminal is one of the links in the LNG supply chain. At this regasification terminal, the LNG is converted to a gas phase at ambient temperature. This heat exchange can be done by using some media, among which are sea water, air, or other media such as propane. In the heat exchange process, the change in temperature $(\Delta \mathrm{T})$ is large enough [6]. These temperature differences produce cold energy, which is in some countries is reused with the following types of utilization [7]:

- Power Plant (Japan, installed capacity of 21,000 kW)

Air separation (Japan, product: Liquid nitrogen, Oxygen, \& Air)

- Refrigeration and Cold Storage (Japan \& South Korea) Air Cooler for Gas Turbine Power Plant Input (India, Japan, Spain)

- Dry Ice Production (Japan, production capacity at LNG Terminal Senboku: 3.3 Ton / year)

- Sea Water Desalination (USA)

- Boiled-off Gas Liquefaction from LNG Tank (Japan \& South Korea)

- Pulverization of Plastics \& Waste at cryogenic temperatures (Japan, crushing handling capacity: 7,000 Ton/year).

Referring to RUPTL 2017 - 2026 [8], in the next few years there will be more number of regasification terminals in Indonesia as supporting infrastructure for Gas/LNG Power Plant. The utilization of cold energy for electricity generation (Cryogenic Power Generation) which has been successfully applied in Japan, then it is also potential to be applied in Indonesia. The benefit of this is to increase the electrical power generated from a power plant beside the electricity generated by a gas engine or gas turbine. This study aims to evaluate the effects of LNG flowrate on working fluid and cooling water flowrates as well as power needed and produced in the combine direct expansion and Rankine cycle processes.

\section{Methods}

This study focuses only on the cryogenic power generation mechanism which is technically implemented in the existing regasification terminal. The Cryogenic power generation mechanism that has been implemented is Cryogenic Power Generation which uses combined direct expansion and Rankine cycle [3]. The technical analysis of the cycle is mainly to calculate the net electrical power generated from the cycle. The approach is to calculate the electrical power of each major component in the cycle, both produced and needed, and then the total power generated is calculated by the equation:

$$
\begin{gathered}
\text { Net Power Generated }= \\
\text { Total Power Generated }- \text { Power Needed }
\end{gathered}
$$

The power generated in the cycle is mainly produced from gas turbine, while the power needed is coming from LNG and working fluid pumps. Calculations of power generated and needed are conducted using UNISIM R390.1. The simulation used propane as a working fluid. Schematic diagram of combined direct expansion and Rankine cycle is presented in Fig. 1 [3]. The LNG is pumped into a given pressure and then is vaporized in working fluid condenser. The natural gas vapor is then heated in gas heater to superheated natural gas and finally is expanded in gas turbine before sending to the customer. Based on Fig. 1, the Net Power Generated can be calculated by:

$$
\begin{gathered}
\text { Net Power Generated }= \\
W_{\mathrm{T}}+W_{\mathrm{TWF}}-W_{\mathrm{PLNG}}-W_{\mathrm{PWF}}-W_{\mathrm{P} 1}-W_{\mathrm{P} 2}
\end{gathered}
$$

where $W_{\mathrm{T}}$ and $W_{\mathrm{TWF}}$ are power produced by gas and working fluid turbine, while $W_{\mathrm{PLNG}}, W_{\mathrm{PWF}}, W_{\mathrm{P} 1}$ and $W_{\mathrm{P} 2}$ are power needed by LNG, working fluid and cooling water pumps, respectively.

\footnotetext{
* Corresponding author: sutrasno@che.ui.ac.id
} 


\section{Results and Discussion}

The basic calculation for the system is summarized in Table 1. The water outlet from vaporizer and gas heater are kept at $5{ }^{\circ} \mathrm{C}$ to prevent water from freezing. Adiabatic efficiencies in all pumps and turbine are set at $75 \%$. The LNG, working fluid and cooling water are pure methane, pure propane and pure water, respectively.

Table 1. Basic calculation data.

\begin{tabular}{|c|c|}
\hline LNG1 & \\
\hline Pressure (PLNG1) & 1.2 Bar (14.8 Psia) \\
\hline Temperature (TLNG1) & $-162^{\circ} \mathrm{C}\left(-260^{\circ} \mathrm{F}\right)$ \\
\hline Composition & Methane $100 \%$ \\
\hline Gas 3 & \\
\hline Pressure $\left(\mathrm{P}_{\mathrm{Gas} 3}\right)$ & 40 Bar (580 Psia) \\
\hline Working Fluid & \\
\hline Pressure $\left(\mathrm{WF}_{1}\right)$ & 1.01 Bar (14.7 Psia) \\
\hline Pressure $\left(\mathrm{WF}_{3}\right)$ & 6.55 Bar (95 Psia) \\
\hline Composition & Propane $100 \%$ \\
\hline Cooling Water & \\
\hline $\begin{array}{l}\text { Pressure (PSW1 in and } \\
\text { PSW2in) }\end{array}$ & 1.01 Bar (14.7 Psia) \\
\hline $\begin{array}{l}\text { Temperature (TSW1 in and } \\
\text { TSW2in) }\end{array}$ & $30^{\circ} \mathrm{C}\left(86^{\circ} \mathrm{F}\right)$ \\
\hline Composition & Water $100 \%$ \\
\hline Gas Heater and Vaporizer & \\
\hline Tube side pressure drop & 0.7 Bar (10 psia) \\
\hline Shell side pressure drop & 0.35 Bar (5 psia) \\
\hline Minimum Approach (spec) & $2.8^{\circ} \mathrm{C}\left(5^{\circ} \mathrm{F}\right)$ \\
\hline WF Condenser & \\
\hline Minimum Approach (spec) & $2.8^{\circ} \mathrm{C}\left(5^{\circ} \mathrm{F}\right)$ \\
\hline
\end{tabular}

The study will evaluate the effects of LNG flowrate on the working fluid and cooling water flowrates as well as power generated and needed by turbines and pumps. The effects of LNG flowrate on working fluid and cooling water flow rates are presented in Fig. 2 and Fig. 3 , respectively. The working fluid and cooling water for gas heater and vaporizer flowrates increase with increasing the LNG flowrate. The increase in LNG flowrate will increase the amount of working fluid that can be condensed in the WF condenser, and therefore more cooling water is needed in vaporizer. The increase in LNG flowrate also increase the water cooling needed in gas heater. The cooling water needed in gas heater is less than in vaporizer due to less LNG mass flowrate as shown in Fig. 2 and gas preheating in working fluid condenser, which led to reducing heating load in gas heater. Furthermore, the line gradient of cooling water needed in vaporizer is higher than in gas heater, indicating that the cooling water needed in vaporizer is more sensitive than cooling water needed in gas heater with increasing the LNG flowrate.

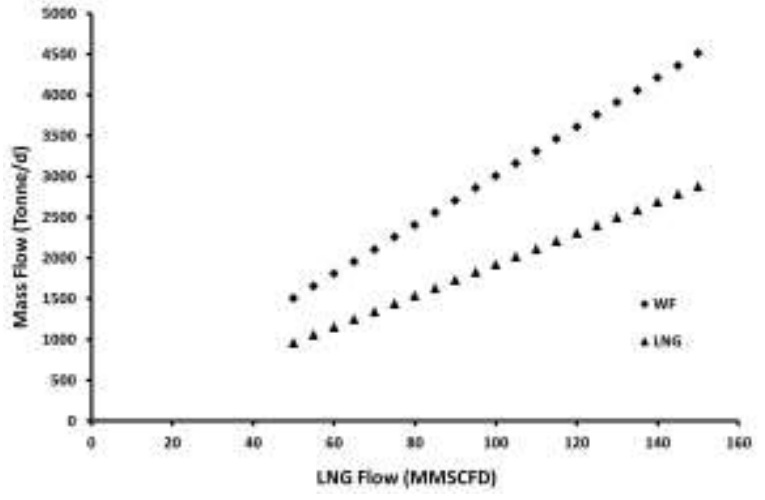

Fig. 2. The effect of LNG flowrate on the working fluid (WF) and natural gas (NG) flowrates.

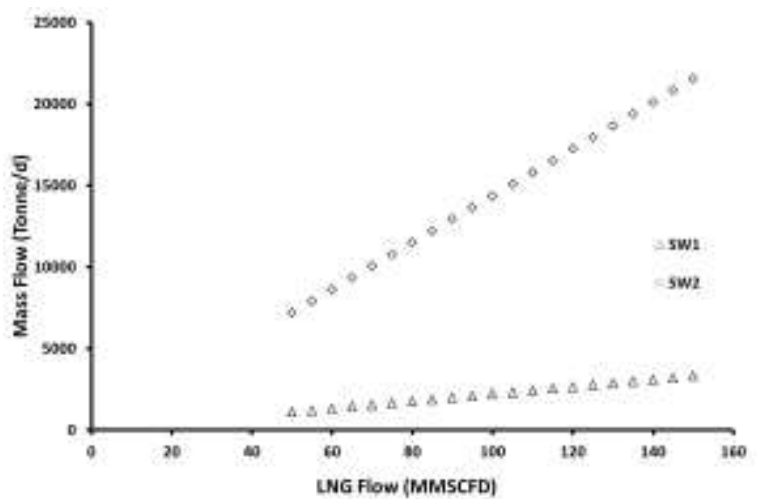

Fig. 3. The effect of LNG flowrate on the cooling water for gas heater $\left(\mathrm{SW}_{1}\right)$ and vaporizer $\left(\mathrm{SW}_{2}\right)$ flowrates.

The effects of LNG flowrate on the power needed by LNG and working fluid pumps are demonstrated in Fig. 4. The power needed by both LNG and working fluid pumps increase with increasing the LNG flowrate due to the increase in the inlet liquid flowrates in both pumps. The power needed by the pump is depend on inlet mass flowrate and pressure ratio between discharge and suction of the pump. The LNG mass flowrate is less than working fluid flowrate as shown in Fig. 2, but pressure ratio in LNG pump is much higher than working fluid pump. The simulation results showed that the power needed in LNG pump is higher than in working fluid pump, indicating that the effect of pressure ratio is more dominant than the effect of mass flowrate. Fig. 4 also shows that the increment gradient of power needed by LNG pump is higher than the increment gradient of power needed by working fluid pump, indicating that the increase in LNG flowrate is more sensitive than working fluid flowrate in consuming energy for pumping. 


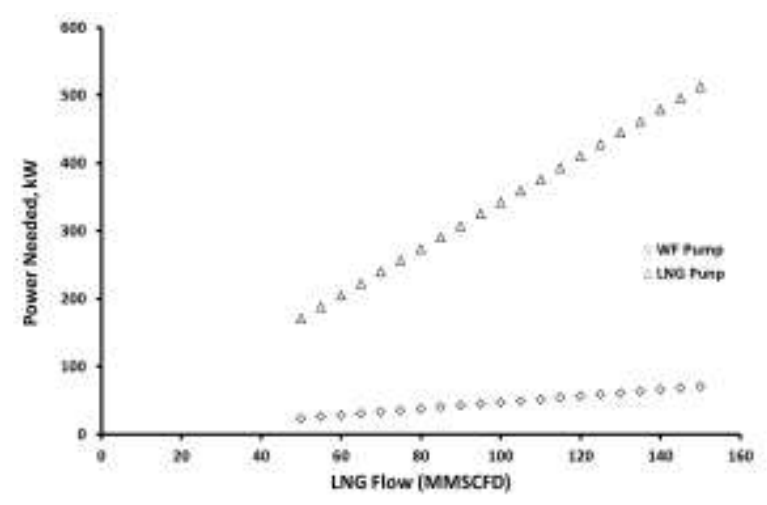

Fig. 4. The effects of LNG flowrate on the power need by LNG and working fluid pumps.

Fig. 5 presents the effects of LNG flowrate on the power needed by the cooling water pumps for delivering water to gas heater and vaporizer, respectively. The power needed by both pumps increase with increasing the LNG flowrate due to the increase in cooling water flowrates as shown in Fig.3. The power needed by the pump for delivering water to vaporizer is higher than the pump for delivering water to gas heater due to the higher mass flowrate of cooling water in vaporizer than in gas heater, as the pressure ratio for both pumps are similar. The gradient of power needed in cooling water for vaporizer is higher than for gas heater, indicating that the power needed in cooling water pump for vaporizer is more sensitive than for gas heater with increasing LNG flowrate.

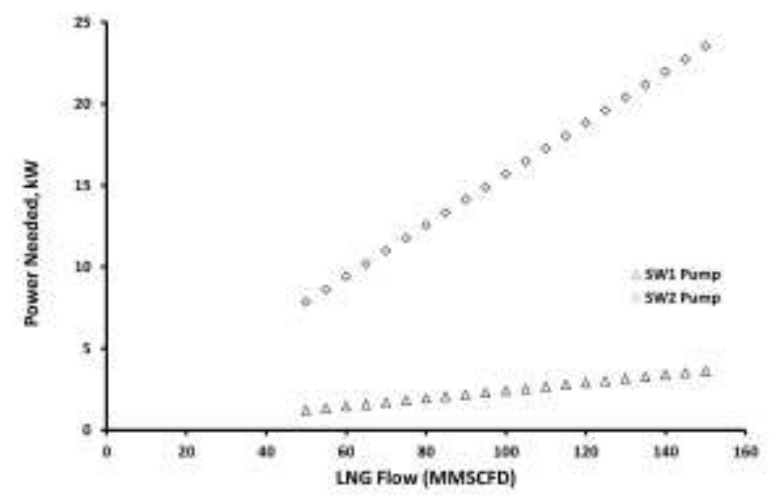

Fig. 5. The effects of LNG flowrate on the power need by cooling water pumps.

Fig. 6 shows the effects of LNG flowrate on the power produced by gas and working fluid turbines and on the net power produced from the cycle. The power produced by gas and working fluid turbines as well as the net power produced increase with increasing the LNG flowrate. The flowrate of LNG will increase the inlet gas flowrates in gas and working fluid turbines as shown in Fig. 2, which led to the increase in the power produced by gas and working fluid turbines. Fig. 6 also shows that the increment gradient of power produced by working fluid turbine is higher than the increment gradient of power produced by gas turbine. It indicates that the increase in working fluid flowrate is more sensitive than LNG flowrate in producing power.

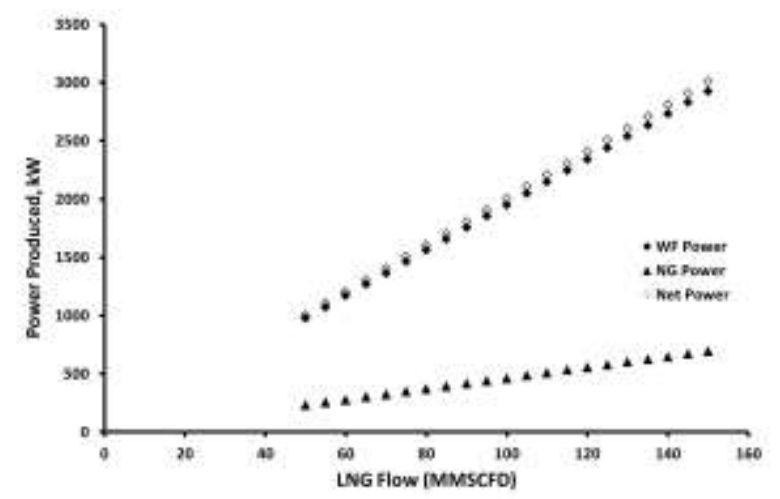

Fig. 6. The effects of LNG flowrate on the power produced by gas and working fluid turbines and on the net power produced.

\section{Conclusions}

The study has been conducted to see the effects of LNG flowrate on working fluid and cooling water flowrates as well as power needed and generated by pumps and turbines in a combined direct expansion and Rankine Cycle process. The simulation results showed that the working fluid and cooling water flowrates increase with increasing the LNG flowrate. The increase in the working fluid and cooling water flowrates also give effect to the increase of power produced by the turbines and needed by the pumps. The overall effects, the net power produced from the combine direct expansion and Rankine cycle process increased with increasing the LNG flowrate.

\section{References}

1. T. Lu, K.S. Wang, App. Therm. Eng. 29, 1478-1484 (2009).

2. Y. Liu, K. Guo, Energy 36, 2828-2833 (2011).

3. M. R. Gómez, R. F. Garcia, J. R. Gómez, and J. C. Carril, Renew. Sust. En. Rev. 38, 781-795 (2014).

4. Kementrian ESDM, Peta Jalan Kebijakan Gas Bumi Nasional 2014-2030, Jakarta (2014).

5. M.M. Foss, C. Head, http://www. beg. utexas. edu/energyecon/lng/documents/CEE_INTRODUCT ION_TO_LNG_FINAL.pdf, 11, 2011 (2007).

6. C. Dispenza, G. Dispenza, V. La Rocca, G. Panno, App. Therm. Eng. 29, 380-387 (2009).

7. K.K.-w. NG, http://www.igemfeds.org/ files/yppc/ 2006\%20Gordon\%20NG.PDF, (2006).

8. PT. PLN, Rencana Usaha Penyediaan Tenaga Listrik 2017-2026, Jakarta, Indonesia (2017). 